\title{
Methyl-CpG-Binding Protein 2
}

National Cancer Institute

\section{Source}

National Cancer Institute. Methyl-CpG-Binding Protein 2. NCI Thesaurus. Code C75729.

Methyl-CpG-binding protein 2 (486 aa, $\sim 52 \mathrm{kDa}$ ) is encoded by the human MECP2 gene.

This protein plays a role in the repression of transcription through binding methylated DNA. 